\title{
IDENTIFIKASI JAMUR PENYEBAB TINEA PEDIS PADA KAKI PENYADAP KARET DI PTPN VIII CIKUPA DESA CIKUPA KECAMATAN BANJAR SARI KABUPATEN CIAMIS TAHUN 2017
}

\author{
Atun Farihatun ${ }^{1}$ Ary Nurmalasari ${ }^{2}$ Ela Hayati ${ }^{3}$ \\ Minceu Sumirah ${ }^{4}$ Doni Setiawan $^{5}$ Panji Wahlanto ${ }^{6}$ \\ $\mathbf{1 , 2 , 3 , 4 , 5}$ Prodi D3 Teknologi Laboratorium Medik STIKes Muhammadiyah Ciamis \\ ${ }^{6}$ Prodi D3 Farmasi STIKes Muhammadiyah Ciamis \\ Email: atunfarihatunmucis@gmail.com
}

\begin{abstract}
Background:Tinea pedis is a disease caused by dermatophyte fungal infections that affect the skin of the toes, the soles of the feet, and the lateral part of the foot. The cause is the genus dermatophyte especially Trichophyton rubrum, and Trichophyton mentagrophytes. The use of closed shoe for long periods of time, increased moisture due to perspiration, rupture of the skin due to mechanical, personal hygiene levels, and exposure to fungi are risk factors that cause tinea pedis. Wet and hot environment conditions in between the fingers due to the use of moist shoes, will also stimulate the growth of fungi. This study aims to determine the Type of Fungus Causes Tinea pedis At Rubber Tapper in PTPN VIII Cikupa Village Cikupa Banjarsari District Ciamis Regency.

Metode: Type is a descriptive study with incidental sampling as well as inclusion and exclusion criteria. The number of samples is 70 samples. Data collection is done by interview and laboratory examination.

Result and conclution:The results of microscopic and macroscopic examination were found positive for Trichophyton rubrum type fungi as many as 10 species (14\%) with colonic forms such as cotton, white base color and grape surface color, positive type of Trichophyton mentagrophytes fungi 2 types (2\%) colony-shaped like cotton, white base color and yellow surface color, and positive species of Aspergillus sp as many as 10 species (14\%) colonyshaped like cotton, black base white color and black and white surface color.
\end{abstract}

Keyword: Tinea pedis, mushroom identification

\section{PENDAHULUAN}

Tinea pedis atau yang lebih dikenal dengan kutu air adalah penyakit akibat infeksi jamur dermatofita yang mengenai kulit pada jari-jari kaki, telapak kaki, dan bagian lateral kaki.Penyebab penyakit ini adalah seluruh genus dermatofita terutama Trichophyton rubrum, dan Trichophytonn, mentagrophytes. Namun penyebab tersering yaitu, Trichophyton rubrum, Trichophyton mentagrophytes, dan Trichophyton epidermophyton floccosum. Penyakit ini merupakan penyakit infeksi dermatofita yang sering terjadi ${ }^{1}$.

Penyadap Karet adalah salah satu jenis pekerjaan yang sehari-harinya

Meditory | ISSN Online : 2549-1520, ISSN Cetak : 2338 -1159, Vol. 6, No. 1, Juni 2018

HIm. $56-60$, http://ejournal.poltekkes-denpasar.ac.id/index.php/M 
Atun Farihatun, dkk., Identifikasi Jamur Penyebab Tinea Pedis pada Kaki Penyadap karet di PTPN VIII Cikupa Desa Cikupa Kecamatan Banjar Sari Kabupaten Ciamis Tahun 2017

menggunakan sepatu yang kedap udara dalam jangka waktu yang lama, sehingga memungkinkan untuk tumbuhnya jamur pada kaki, selain itu tingkat kebersihan yang kurangdiperhatikan juga merupakan salah satu faktor penyebab tumbuhnya jamur.

Selain karena pemakaian sepatu tertutup untuk waktu yang lama, bertambahnya kelembaban karena keringat, pecahnya kulit karena mekanis, tingkat kebersihan perorangan, dan paparan terhadap jamur merupakan faktor resiko yang menyebabkan terjadinya tinea pedis. Kondisi lingkungan yang lembab dan panas di sela-sela jari karena pemakaian sepatu yang lembab, juga akan merangsang tumbuhnya jamur ${ }^{2}$

Berdasarkan survey pendahuluan yang dilakukan peneliti terlihat bahwa penyadap karet di PTPN VIII memakai sepatu boot yang kedap udara dan dipakai pada waktu yang lama sehingga keadaan kaki yang memakai sepatu tersebut menjadi lembab dan memungkinkan tumbuhnya jamur serta ada keluhan gatal pada sela jari kaki dan telapak kaki yang pecah-pecah.

Penelitian ini bertujuan untuk mengetahui Jenis Jamur Penyebab Tinea Pedis Pada Penyadap Karet di PTPN VIII Cikupa Desa Cikupa Kecamatan Banjarsari Kabupaten Ciamis.

\section{METODE}

Jenis penelitian yang digunakan dalam penelitian adalah penelitian deskriptif yaitu untuk mendeskripsikan hasil pemeriksaan identifikasi Tinea pedis pada Penyadap Karet di PTPN VIII Cikupa Desa Cikupa Kecamatan Banjarsari Kabupaten Ciamis. Populasi penelitian adalah total populasi, dengan sampel sebanyak 70 sampel. Tenik sampling dilakukan secara incidental sampling dengan kreteria inklusi dan eksklusi. Pengumpulan data dilakukan dengan wawancara dan pemeriksaan laboratorium, dengan procedure kerja meliputi tahapan persiapan alat dan pembuatan media, penanaman sampel pada media dan pemeriksaan sampel

Data yang diperoleh dari hasil pemeriksaan laboratorium tentang Jamur Penyebab Tinea pedis pada penyadap karet di PTPN VIII diolah dan disajikan secara deskriptif dalam bentuk tabel dan dijelaskan secara narasi.

\section{HASIL}

Hasil pemeriksaan secara makroskopis teridentifikasi Trichophyton rubrum bentuk koloni seperti kapas, warna dasar putih dan warna permukaan merah anggur. Jamur Trychophyton mentagrophytes berbentuk koloni seperti

Meditory | ISSN Online : 2549-1520, ISSN Cetak : 2338 - 1159, Vol. 6, No. 1, Juni 2018 
Atun Farihatun, dkk., Identifikasi Jamur Penyebab Tinea Pedis pada Kaki Penyadap karet di PTPN VIII Cikupa Desa Cikupa Kecamatan Banjar Sari Kabupaten Ciamis Tahun 2017

kapas, warna dasar putih dan warna permukaan kuning. Jamur Aspergillus sp berbentuk koloni seperti kapas, warna dasar putih hitam dan warna permukaan hitam putih (table 1).

Hasil pemeriksaan secara mikroskopis ditemukan positif jenis jamur
Trichophyton rubrum sebanyak 10 jenis (14\%), positif jenis jamur Trichophyton mentagrophytes sebanyak 2 jenis (2\%), dan positif jenis jamur Aspergillus $s p$ sebanyak 10 jenis (14\%) (tabel 2).

Tabel 1

Hasil pemeriksaan Makroskopis Jamur Penyebab Tinea pedis

\begin{tabular}{|l|l|l|l|l|}
\hline \multirow{2}{*}{ No } & \multicolumn{1}{|c|}{ Jenis Jamur } & Hentuk koloni & Warna dasar & $\begin{array}{l}\text { Warna } \\
\text { permukaan }\end{array}$ \\
\cline { 3 - 5 } & Trichophyton rubrum & Seperti kapas & Putih & $\begin{array}{l}\text { Merah } \\
\text { Anggur }\end{array}$ \\
\hline 2 & $\begin{array}{l}\text { Trychophyton } \\
\text { mentagrophytes }\end{array}$ & Seperti kapas & Putih & Kuning \\
\hline 3 & Aspergillus sp & Seperti kapas & Putih hitam & Hitam Putih \\
\hline
\end{tabular}

Tabel 2

Hasil pemeriksaan Mikroskopis Jamur Penyebab Tinea pedis

\begin{tabular}{|c|l|c|}
\hline No & \multicolumn{1}{|c|}{ Jenis jamur } & Positif \\
\hline 1 & Trichophyton rubrum & 10 \\
\hline 2 & Trychophyton mentagrophytes & 2 \\
\hline 3 & Aspergillus sp & 10 \\
\hline
\end{tabular}

\section{PEMBAHASAN}

Jamur sangat erat kaitannya dengan manusia.Jamur bisa hidup dan tumbuh dimana saja, baik di udara, tanah, air pakaian, bahkan ditubuh manusia sendiri.Indonesia sebagai negara tropis menjadi lahan subur tumbuhnya jamur khususnya jamur Trichophyton rubrum. Oleh sebab itu, penyakit-penyakit akibat jamur ini seringkali menjangkiti masyarakat.

Trichophyton rubrum menyerang jaringan kulit dan menyebabkan infeksi kulit antara lain : Tinea Pedis ("Athlete's Foot') yang berlokasi diantara jari-jari kaki, dan telapak kaki infeksi ini banyak terdapat pada orang yang kerap memakai sepatu, Tinea Cruris (“Jocktitch”) yang

Meditory | ISSN Online : 2549-1520, ISSN Cetak : 2338 - 1159, Vol. 6, No. 1, Juni 2018

HIm. 56-60, http://ejournal.poltekkes-denpasar.ac.id /index.php/M 
Atun Farihatun, dkk., Identifikasi Jamur Penyebab Tinea Pedis pada Kaki Penyadap karet di PTPN VIII Cikupa Desa Cikupa Kecamatan Banjar Sari Kabupaten Ciamis Tahun 2017

berlokasi dilipatan paha, Tinea Barbae yang berlokasi dirambut janggut, dan Tinea Ungunium yang berlokasi di kuku tangan maupun kaki. Kita dapat mencegah infeksi jamur dengan selalu memperhatikan kebersihan diri dan menjaga kekebalan tubuh (Jawetz, 2008).

Taksonomi dari Trichophyton rubrum adalah sebagai berikut

Phylium : Askomykota

Class : Eurityomycetes

Order : Onygenales

Family : Arthroder mataceae

Genus : Tricopyton

Spesies :Trichophyton rubrum

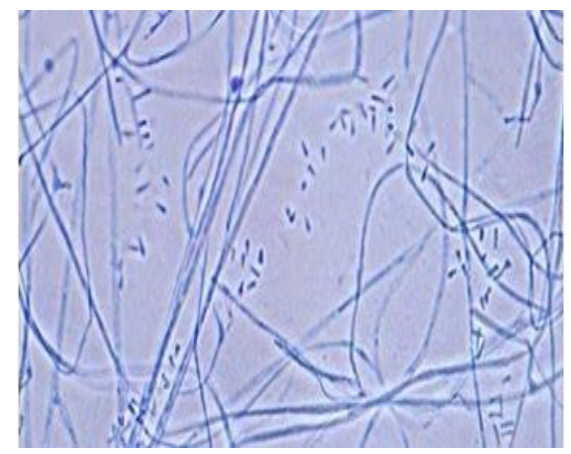

Gambar Mikroskopis Jamur Trichophyton rubrum ${ }^{3}$.

Pada jamur ini, mikrokonidia adalah bentuk spora yang paling banyak, mikrokonidia berdinding halus, berbentuk tetesan air mata sepanjang sisi-sisi hifa, pada beberapa strain terdapat banyak mikrokonidia bentuk ini, koloni sering menghasilkan warna merah pada sisi yang sebaliknya, beberapa strain dari T. rubrum telah dibedakan yaitu : T. rubrum berbulu halus dan $T$. rubrum tipe granule, $T$. rubrum berbulu halus memiliki karakteristik yaitu produksi mikrokonidia yang jumlahnya sedikit, halus, tipis, kecil, dan tidak mempunyai makrokonidia. Sedangkan karakteristik $T$. rubrum tipe granuler yaitu produksi mikrokonidia dan makrokonidia yang jumlahnya sangat banyak, mikrokonidia berbentuk clavate dan pyriform, makrokonidia berdinding tipis, dan berbentuk seperti cerutu, $T$. rubrum berbulu halus adalah strain jamur yang paling banyak menginfeksi manusia. Strain ini dapat menyebabkan infeksi kronis pada kulit. Sedangkan T. rubrum tipe granular menyebabkan panyakit Tinea corporis $^{4}$.

Trichophyton rubrum menginfeksi rambut, kulit dan kuku, membentuk makrokonidia silindris dengan dinding tipis, halus, club-sheped dengan 8-10 septum dengan ukuran $4 \times 8-8 \times 15 \mu \mathrm{m}$ dan mikrokonidia yang khas berbentuk bulat, piriform ( teardrop-shaped), atau clavate (club shaped) dengan ukuran 2-4 $\mu \mathrm{m}$. Sifat umum Trichophyton rubrum :

a. Dermatophytes antropofik

b. Infeksi rambut, kulit dan kuku.

Meditory | ISSN Online : 2549-1520, ISSN Cetak : 2338 - 1159, Vol. 6, No. 1, Juni 2018

HIm. 56 - 60, http://ejournal.poltekkes-denpasar.ac.id /index.php/M 
c. Ectothricx, tes urease negatif, hair perporation test negatif.

\section{DAFTAR PUSTAKA}

d. Biakan (kultur): tumbuh lambat (2-3 minggu), koloni putih sepeij bludur (velvety), ditutupi oleh aireal miselium, memberi pigmen merah anggur dilihat dari reverse side.

Gambaran mikroskopik dari biakan ${ }^{5}$ :

a. Berdinding tipis

b. Bentuk septa kecil

c. Bentuk lonjong seperti tetesan air mata

d. Membentuk banyak mikrokonidia

1. Departemen Parasitologi FKUI, Buku Ajar Parasitologi Kedokteran Edisi 4. Penerbit : Balai Penerbit FKUI, Jakarta. 2008

2. Irianto, K. Bakteiologi Medis, Mikologi Meis, dan Virologi Medis. Bandung : Alfabeta . 2014

3. Gunter, Robert. Trichophyton rubrum Microbiology.http://soils1.cses.ut.edu/. 2005

4. Jawetz, dkk Mikrobiologi Kedokteran.Jakarta : EGC. .2008.

5. Gandjar, Indrawati, dkk. Mikologi: Dasar dan Terapan. Jakarta : IKAPI DKI. 2014

\section{SIMPULAN DAN SARAN}

\section{Simpulan}

Jenis jamur penyebab Tinea pedis pada penyadap karet di PTPN VIII Cikupa Desa Cikupa Kecamatan Banjarsari Kabupaten Ciamis adalah Trichophyton rubrum sebanyak 10 jenis , Trichophyton mentagrophytessebanyak 2 jenis dan Aspergillus sp sebanyak 10 jenis.

\section{Saran}

Bagi peneliti selanjutnya disarankan untuk meneliti jenis jamur lain yang belum teridentifikasi. 